\title{
Litteracitetspraktiker $i$ vardags- och samhällsliv: Skriftspråksvanor hos svenska sfi-elever med kort eller ingen tidigare studiebakgrund
}

\author{
Åsa Wedin ${ }^{1 \star}$ och Annika Norlund Shaswar ${ }^{2}$ \\ ${ }^{1}$ Institutionen för språk, litteratur och lärande, Högskolan Dalarna, Sverige; ${ }^{2}$ Institutionen \\ för språkstudier, Umeå universitet, Sverige
}

\section{Sammandrag}

Syftet med denna artikel är att skapa kunskap om litteracitetspraktiker hos elever med kort eller ingen tidigare skolbakgrund inom svenska för invandrare. Med utgångspunkt i New Literacy Studies studeras elevernas tal om händelser, färdigheter och strategier som aktualiseras för dem i deras vardagsliv. Nio elever deltog i intervjuer som utgick från deras egna fotografier. Utifrån intervjuerna framträder en bild av elevernas användning av skrift för meningsskapande, deras litteracitetspraktiker. Engagemanget bland de intervjuade var stort i frågor som rörde ekonomi, liksom kreativiteten vad gäller att skapa strategier för att lösa frågor relaterade till skriftspråksanvändning, såsom vid inköp till hushållet. Där beskrev de intervjuade utvecklade strategier både för ekonomisk planering och kritiskt förhållningssätt som konsument. Relationer mellan undervisningen och maktrelationer i lokala diskurser framträder bland annat i form av elevernas beroende av välvilliga mediatorer och av digitala resurser som är kopplade till ekonomiska möjligheter. Alltför begränsade färdigheter riskerar att leda till en begränsning av samhälleligt deltagande och svårigheter med att utöva medborgerliga rättigheter. Genom att lärare får kännedom om strategier som eleverna använder i vardagslivet kan undervisningen utvecklas på sätt som gynnar elevernas andraspråksutveckling.

Nyckelord: Svenska för invandrare; litteracitetspraktiker; vuxnas skriftspråksvanor

\begin{abstract}
Literacy practices in everyday life and society: Literacy habits among students studying Swedish for immigrants who have little or no previous schooling

The aim of this article is to contribute to knowledge about literacy practices among students studying Swedish for immigrants, who have little or no previous schooling. With a basis in New Literacy Studies, students' talk about events, skills and strategies used in their everyday life is investigated. Nine students participated in the interviews and their own photographs were used as a basis for discussion. A picture emerged of their use of writing for creating meaning; their literacy practices. The participants were very interested in discussing money matters, and they suggested creative strategies for solving issues related to the use of written language in situations such as when making purchases for the household. Here the participants described well-developed strategies for
\end{abstract}

^Korrespondens: Åsa Wedin, e-mail: awe@du.se

(C) 2021 Åsa Wedin \& Annika Norlund Shaswar. This is an Open Access article distributed under the terms of the Creative Commons Attribution 4.0 International License (https://creativecommons.org/licenses/by/4.0/), allowing third parties to copy and redistribute the material in any medium or format and to remix, transform, and build upon the material for any purpose, even commercially, provided the original work is properly cited and states its license. 


\section{A. Wedin och A. N. Shaswar}

managing money and being a discerning consumer. The relationship between teaching and power relations in local discourses is observed in the students' dependence on benevolent mediators and on digital resources which are related to money. Limited proficiency can lead to a lack of societal participation and difficulty exercising one's civil rights. By raising awareness among teachers about strategies that students use in everyday life, teaching can be developed in ways that benefit students' second language development.

Keywords: Swedish for immigrants; literacy practices; literacy habits among adults

Responsible editor: Gustaf B. Uno Skar

Received: January, 2021; Accepted: September, 2021; Published: November, 2021

\section{Introduktion}

I denna artikel studeras litteracitetspraktiker hos elever med kort eller ingen tidigare skolbakgrund inom svenska för invandrare (sfi) för att skapa kunskap som behövs för att utbildning i grundläggande litteracitet och andraspråk för vuxna i högre grad ska kunna bygga vidare på elevers erfarenheter och behov. Intresset riktas mot elevernas användning av skrift i sina liv utanför skolan, i vardags-, samhälls- och arbetsliv, genom att undersöka vilka litteracitetspraktiker de deltar i. Fokuset på litteracitetshändelser, och de litteracitetspraktiker dessa ingår i, innebär att vi intresserar oss för vanor, attityder och förståelse i relation till skrift (Barton \& Hamilton, 1998, p. 6-7, 2000, p. 7; Hamilton, 2000, p. 16; Street, 1993, p. 12-13). I litteracitetspraktiker inkluderar vi även strategier som elever använder när de upplever att deras egna litteracitetsfärdigheter inte räcker till för det de vill göra.

I många länder innebär globala migrationsprocesser ett ökande behov av språkundervisning för vuxna i landets dominerande språk. Funktionella färdigheter i det nya språket, det vill säga färdigheter som individen själv finner användbara i vardagslivet, är ofta en viktig nyckel till arbete och social integration (se exempelvis Bialystok, 2001). I Sverige organiseras denna undervisning genom svenska för invandrare (sfi) och finansieras med offentliga medel. Sfi består av fyra kurser, A-D, som organiseras $i$ tre studievägar. I denna studie ligger fokus på studieväg ett, som riktar sig till elever med kort eller ingen tidigare skolbakgrund och vilka tidigare haft små möjligheter att utveckla färdigheter vad gäller skrift.

Sfi-undervisning inom studieväg ett innebär stora utmaningar, inte minst vad gäller utveckling av litteracitetsfärdigheter. Kraven på färdigheter i svenska är höga i Sverige för deltagande i vardags-, samhälls- och arbetsliv, vilket innebär särskilt stora utmaningar för den aktuella gruppen (Skolverket, 2017). Enligt såväl lärare som elever vi möter i olika sammanhang ställer arbetsgivare ofta krav på att man uppnått en viss nivå inom sfi, exempelvis uppnådd D-nivå, motsvarande B1/B1+ enligt SOU 2013:76. Detta innefattar krav på litteracitetsfärdigheter. Vissa av dessa elever ska kanske för första gången utveckla grundläggande läs- och skrivförmåga och detta sker på svenska, ett språk som de på samma gång ska lära sig. Samtidigt är den befintliga forskningen fragmentarisk och har sällan fokuserat didaktiska frågor (Lundgren et al., 2017; 
Skolinspektionen, 2018). I jämförelse med ungdomsskolan är målen för sfi funktionellt riktade genom att eleverna, utöver att ges möjlighet att bedriva vidare studier, även ska ges förutsättningar att utveckla sina kunskaper och sin kompetens för att stärka sin ställning som vuxna i arbets- och samhällslivet och samtidigt främja sin personliga utveckling, enligt Skollagen (SFS 2010:800, kap. 2 §). Detta ställer således höga krav på såväl lärare som elever.

Genom intervjuer med elever på studieväg ett skapas här kunskap om litteracitetspraktiker av betydelse för eleverna. Intervjuerna fokuserade på litteracitet som inte var direkt relaterad till skolarbetet. Studien bidrar därmed till att lägga en grund för vidare utveckling av undervisning av relevans för den aktuella gruppen. Det specifika syftet är att skapa kunskap om litteracitetspraktiker som sfi-elever på studieväg ett, kurs $\mathrm{A}$ och $\mathrm{B}$, ingår $\mathrm{i}$ utanför skoldomänen för att ge insikt om utbildningsbehov. Följande frågeställningar kommer att besvaras:

1. Vilka litteracitetshändelser ges uttryck för i elevernas tal?

2. I vilken utsträckning och i vilka avseenden uttrycker eleverna att deras färdigheter är tillräckliga för dessa händelser?

3. Vilka strategier uttrycker eleverna för att hantera situationer där de upplever att deras egna litteracitetsfärdigheter inte räcker till?

\section{Teoretisk utgångspunkt}

Den teoretiska grunden för denna studie tas i Streets ideologiska syn på skrift (1993, 1995) där litteracitet betraktas som ett fenomen som inte bara består av separata färdigheter i hjärnan eller existerar enbart i texten i sig, utan även som ett fenomen mellan tanke och text och därmed som en resurs som kan användas på en mängd olika sätt. Inom det tvärvetenskapliga forskningsfältet New Literacy Studies har ett perspektiv utformats där litteracitet förstås som sociala praktiker vilka lärs in och används på olika sätt i olika sammanhang beroende på vilka politiska, sociala och kulturella mönster som dominerar där (Barton, 2001; Baynham \& Prinsloo, 2009; Street, 1984, 2003, 2009). Med utgångspunkt i Scribner och Cole (1981) och Heath (1983) utvidgade Street begreppet literacy practices (2003, p. 79) till att avse "the broader, cultural conception of particular ways of thinking about and doing reading and writing in cultural contexts". Sålunda utgör begreppet ett kraftfullt sätt att begreppsliggöra relationen mellan olika litteraciteter och de sociala strukturer de är inbäddade i (Barton, 2001; Street, 1995) och refererar därmed till både beteende och de sociala och kulturella förståelser där läsning och/eller skrivning används för meningsskapande. Den svenska översättningen litteracitetspraxis överensstämmer i högre grad med det engelska begreppet än dess variant litteracitetspraktiker, eftersom praktik för tankarna till en konkret aktivitet medan litteracitetspraktik är ett begrepp på en abstrakt nivå. Begreppet innefattar såväl konkreta och synliga aspekter (handlingar som att föra en penna mot ett papper eller att föra ett samtal om en skönlitterär bok) som abstrakta och mer osynliga aspekter (såsom känslor, attityder och 
identitet relaterade till litteracitet). Vi väljer ändå att här använda det senare, litteracitetspraktiker, eftersom det har blivit mer gängse men vill betona att vi med praktiker inte syftar på de konkreta observerbara händelserna, litteracitetshändelser, utan just på bakomliggande attityder, vanor och förståelse som vi tolkar att händelserna är uttryck för.

Street (2011) argumenterade för vikten av att förstå litteracitetspraktiker för att undvika förenklade och etnocentriska anspråk vad gäller skrift utifrån endimensionella och kulturellt snäva kategorier och definitioner och vikten av att göra sig känslig för aspekter av makt och ojämlikhet i relation till skrift. Genom att använda ett kritiskt perspektiv på litteracitet (Freire, 1970; Martin-Jones, 2007) utgår vi i denna studie från att elevernas egna språkliga repertoarer kan utnyttjas för att stärka deras andraspråkslärande i sfi-klassrummet. Med Martin-Jones poststrukturalistiska utgångspunkt används kritisk för att visa kopplingar mellan lokala diskurspraktiker som en utveckling av Freires ursprungliga fokus på befrielse av de förtryckta (se t.ex. Pennycook, 2003). Denna poststrukturalistiska tradition har bland annat använts för att analysera maktrelationer i klassrum kopplade till lokala diskurser (Martin-Jones, 2007). Genom att rikta intresset mot de erfarenheter eleverna har och de strategier de använder i sin vardag (se även Barton et al., 2007) vill vi här studera möjligheter till förändring.

Inom New Literacy Studies har ett flertal studier fokuserat på klassrum där lärares och elevers bakgrund skiljer sig vad gäller etniska, sociala och kulturella faktorer och vad som sker när elevernas litteracitetspraktiker från vardagslivet möter skoldomänens litteracitetspraktiker (Dantas \& Manyak, 2010; Heath, 1982; Li, 2009; Norlund Shaswar, 2014; Purcell-Gates., 2007). För denna studie är även begreppet funds of knowledge relevant. Detta står för en förståelse av inlärare som kompetenta personer med livserfarenheter som ger dem kunskaper och har använts för att undersöka vad elever läser och skriver i sina vardagsliv utanför skoldomänen (González et al., 2005). Funds of knowledge riktar fokus på styrkor i elevernas litteracitetspraktiker och kunskaper baserade i vardagslivet samt på hur dessa kan utgöra en kunskapsbank för lärare och elever $\mathrm{i}$ undervisningen. Begreppet stöder här studiet av elevernas meningsskapande i vardagslivet.

Den ideologiska synen på litteracitet (Street, 1993, 1995) innebär att inläraren betraktas som aktiv i inlärningsprocessen genom att i social interaktion ifrågasätta, utmana, acceptera eller hävda olika identiteter i förhandling med andra. För detta är olika inlärarstrategier betydelsefulla, inte minst olika kommunikationsstrategier (se exempelvis Griffiths, 2013; Oxford et al., 2014). Genom användande av kommunikationsstrategier kan inläraren utföra sådana språkhandlingar för vilka den egna språkförmågan ännu inte räcker. Detta är särskilt betydelsefullt för vuxna andraspråksinlärare, såsom elever på studieväg ett på sfi som behöver använda svenska i skriftlig form innan de själva hunnit utveckla sådana färdigheter i läsning och skrivning på svenska som krävs. Det innebär att strategier här betraktas som individers agerande i sitt meningsskapande för att nå vissa kommunikativa mål. 


\section{Tidigare forskning}

Vuxnas strategier för användning av litteracitet $\mathrm{i}$ vardagslivet har bland annat utforskats inom New Literacy Studies (se t.ex. Barton et al., 2007; Vollmer, 2019). I nordamerikansk kontext har ett antal studier med fokus på lärande av ett andraspråk utifrån ett kritiskt perspektiv genomförts, där intersektioner mellan genus, klass, etnicitet och språk uppmärksammats (Menard-Warwick, 2009; Norton 2013, 2015; Skilton-Sylvester, 2002; Warriner, 2010). Norton menar, i likhet med Cummins (2017), att lärande av ett andraspråk snarare handlar om engagemang och investering än om individuell motivation. Norton (2013) framhåller att ojämlika maktstrukturer i samhället kan begränsa inlärares möjligheter att interagera på det aktuella språket utanför klassrummet, vilket i sin tur påverkar deras möjligheter till språkutveckling. Cummins betonar vikten av engagemang för en framgångsrik utveckling av färdigheter i läsning och skrivning. I Skilton-Sylvesters studie (2002) visades den betydelse identitetsprocesser i relation till famili, arbetsliv och kulturell tillhörighet har för andraspråksutvecklingen (se även Ahlgren, 2014; Cooke, 2006).

I en översikt av forskning om vuxnas lärande av ett andraspråk betonas just bristen på didaktisk forskning inom sfi (Lundgren et al., 2017; SOU 2020:66; för nordisk kontext se även Monsen \& Pájaro, 2021). Forskning om sfi har bland annat studerat sfi-deltagares erfarenhet av utbildningen (Carlson, 2002) och hur de ser på vad det innebär att kunna ett språk (Rydell, 2018) samt identitet och kategoriseringar i styrdokument och i klassrumsinteraktion (Rosén, 2013). Andra studier har undersökt sfi-utbildningens organisation och dess mångfacetterade och till viss del ambivalenta mål (Carlson, 2002; Lindberg \& Sandwall, 2017; Rosén, 2013). När det gäller lärarperspektiv har bildanvändning i grundläggande litteracitetsundervisning studerats (Franker, 2011) samt hur lärare formar sin identitet och sin undervisning i relation till deltagarnas behov av att både lära sig svenska och grundläggande litteracitet (Colliander, 2018). Lundgren (2005) och Norlund Shaswar (2014) har undersökt sfi-elevers erfarenheter av litteracitet. Norlund Shaswar betonar särskilt potentialen $i$ att utveckla användningen av digitala resurser. Endast begränsad forskning har genomförts när det gäller grundläggande skriftspråksundervisning för vuxna (Wedin et al., 2018, se även Malessa (2018) för Finland, Monsen (2021) för Norge, samt Choi \& Ziegler (2015) för Luxemburg, Kanada och Belgien), och då främst i utvecklingsländer (Kerfoot, 2009; Papen, 2005; Prinsloo \& Breier, 1996; Wedin, 2007).

Vad gäller Luxemburg efterlyste Choi och Ziegler (2015) systematisering av kursplaner och bedömning samt utveckling av lärarutbildning med inriktning mot lågutbildade vuxna. Malessa (2018) framhåller särskilt sociala utmaningar kopplade till den aktuella elevgruppen och deras skriftspråksutveckling och liksom Choi och Ziegler betonar hon vikten av att utveckla relevanta undervisningsmetoder. Samtidigt framhåller Malessa vikten av att utveckla potentialen med digitala och teknologiska verktyg. Lam, Warriner, Poveda och González (2012) understryker betydelsen av att 
utforska användningen av språk och litteracitet i hem och vardagsliv, inte minst för att visa betydelsen av gränsöverskridande och transnationella informationsflöden. De menar, liksom Noguerón-Liu (2013), att studier av hur migranter navigerar och positionerar sig inom och över nationella gränser är av stort värde för skola och undervisning, inte minst vad gäller transnationella sociala nätverks potential som resurser.

Forskning om lågutbildade vuxnas litteracitetspraktiker är således relativt begränsad och fragmentarisk, vilket motiverar denna studie.

\section{Metod och material}

Denna studie ingår i ett större projekt, Grundläggande litteracitetsundervisning inom $s f i{ }^{1}$ Projektet genomförs som ett aktionsprojekt med utgångspunkt i lingvistisk etnografi (Copland \& Creese, 2015). Upplägget med praxisnära aktionsforskning i kombination med lingvistisk etnografi erbjuder verktyg för att skapa förståelse av de komplexa och flerskiktade fenomen som är aktuella (Canagarajah, 2006; Hornberger \& Johnson, 2017; Zeichner, 2001). För att skapa förutsättningar för utveckling av undervisningspraktiker är kännedom om elevernas erfarenheter, perspektiv och behov i relation till undervisningen betydelsefull. Därför genomfördes inledningsvis intervjuer med eleverna (se t.ex. Cooke, 2006) för att skapa kunskap om deras litteracitetspraktiker i vardagslivet. Projektet inkluderar fyra skolor, men för denna studie har nio elevintervjuer från en av dessa använts. Dessa har genomförts i form av stimulated recall utifrån elevers egna fotografier (Haglund, 2003). Fotografier användes här för att stimulera eleverna att reflektera kring sina vardagliga litteracitetshändelser och de litteracitetspraktiker de ingår $i$, inklusive olika strategier de använde i samband med skrift (se exempelvis Prosser \& Loxley, 2008). Fotografierna hjälpte till med att överbrygga mellan konkreta litteracitetshändelser och de mer abstrakta litteracitetspraktikerna. Inför intervjun ombads eleverna att fotografera situationer i sitt liv utanför skolan där skrift ingick. Fotograferandet gjordes med elevernas egna mobiler och bilderna användes sedan som utgångspunkt för intervjuerna som fokuserade elevernas användning av skrift i olika sammanhang där de ingår. Med denna visuellt etnografiska ansats (Pink, 2014) stärktes elevernas roll i intervjun genom att utgångspunkt togs $\mathrm{i}$ deras egen dokumentation.

Under den tid som studien genomfördes bedrevs en stor del av skolarbetet av eleverna hemma till följd av rådande covid-19-pandemi. Elevernas undervisningstid i skolan var begränsad till några timmar per vecka och övrigt skolarbete genomförde de med hjälp av dator eller mobil via en blogg där läraren lade ut uppgifter och hanterade kommunikationen med eleverna. Detta innebar att skolrelaterat läsande och skrivande i större utsträckning än vanligt kunde förväntas pågå i hemmen, men fokus vid intervjuerna låg på litteracitetshändelser som inte hade direkt koppling till skolarbetet. Fotografierna blev här en konkretisering av vårt intresse av

\footnotetext{
${ }^{1}$ 2020-2022, finansierat av Skolforskningsinstitutet 201900027.
} 
litteracitetshändelser utanför skolan som underlag för att skapa förståelse för litteracitetspraktiker i vardagen.

Vid urval av elever valdes speciellt sådana som av lärarna uppfattades ha svag progression för att identifiera litteracitetspraktiker av värde för de elever som har mött stora svårigheter för sin skriftspråksutveckling i sfi. I urvalet ingår sju elever med somalisk bakgrund, här kallade Yosuf, Hamsa, Hasan, Hanifa, Zeyneb, Shukri och Habibu, och två med kurdisk bakgrund, Salma och Dimal. Detta innebär att de språk som användes vid intervjuerna var somaliska respektive kurmanji (nordkurdiska). Av de intervjuade var det ingen som hade praktikplats och endast en hade någon form av betalt arbete, och i detta fall i form av timanställning vid behov.

Den aktuella elevgruppen består av personer i mer eller mindre utsatt situation och stor vikt lades såväl vid etiska frågor av olika slag som vid frågor som rör själva intervjuförfarandet (Norlund Shaswar, 2021). Vid information och inhämtande av samtycke till deltagande i studien användes blanketter som fanns såväl översatta till som ljudinspelade på elevernas olika språk. Dessutom togs i de flesta fall även studiehandledare till hjälp för att ytterligare förklara vad deltagande kan innebära. Allt material förvaras oåtkomligt för obehöriga och presentationen i artikeln sker på sätt som ska förhindra identifiering. Det innebär exempelvis att samtliga namn är fiktiva. Intervjuerna genomfördes med hjälp av tolk eller studiehandledare på de sätt som vi fann lämpligast. Fem av intervjuerna genomfördes individuellt med hjälp av studiehandledare som var känd för eleverna. I studiehandledarens roll ingår inte att tjänstgöra som tolk men samtidigt var det en fördel för eleverna att denna redan var bekant. Vid de återstående två intervjuerna användes professionell tolk i vardera intervjun med två elever samtidigt. Professionaliteten innebar att tolkningen genomfördes mer enligt tolkpraxis och situationen med en mindre känd person närvarande uppvägdes i viss mån av att de som intervjuades tillsammans i förväg hade goda relationer med varandra. Samtidigt innebar gruppintervjusituationen en risk för att någon enskild elev i lägre grad kom till tals.

På grund av de villkor för intervjuerna som tolkförfarandet innebar har enbart det som sagts på svenska transkriberats. Det bedömdes som tillräckligt för denna studies syfte, och att den ytterligare information som kan finnas i interaktion på andra språk mellan tolk och elever inte skulle tillföra tillräckligt mycket mer för att motivera den stora insats ytterligare transkription skulle innebära. Det innebär att citat som anges i resultatdelen behöver betraktas som just tolkat eller översatt tal.

För att analysera de litteracitetspraktiker som de intervjuade eleverna ingår i har en tematisk innehållsanalys genomförts. Det innebär att analysen har inriktats på vad som sägs, innehållet, och att detta har tematiserats för att urskilja mönster. Den specifika situation som dessa intervjuer innebar, med personer i relativt utsatt situation och med hjälp av tolk eller studiehandledare, har medfört att vi av etiska skäl inte presenterar de intervjuade närmare och avstår från att göra analyser av enskilda individers litteracitetspraktiker. I stället väljer vi att se dessa nio som exempel på elever inom studieväg ett på kurs $\mathrm{A}$ och $\mathrm{B}$. 
Analysen genomfördes stegvis. I ett första steg genomlästes transkriptioner för att identifiera sådant som kan utgöra grund för besvarande av forskningsfrågorna. Vid behov lyssnades delar av inspelningarna igenom ytterligare flera gånger. Först identifierades alltså de olika slags litteracitetshändelser som eleverna ger uttryck för i sitt tal, därefter deras uttryck om sina färdigheter i relation till dessa händelser och slutligen de strategier de säger sig använda för att hantera litteracitetshändelser där de upplever att deras egna språkfärdigheter inte räcker till. I ett andra steg söktes teman och mönster bland de exempel som hänfördes till respektive fråga. I ett tredje steg utgjorde respektive del utgångspunkt för att analysera fram vilka litteracitetspraktiker som kunde förstås utifrån detta. Sålunda analyseras de konkreta litteracitetshändelserna så som de framträder i elevernas tal, för att skapa en förståelse för de litteracitetspraktiker de är uttryck för. Genom hela analysprocessen har Streets ideologiska syn på litteracitet $(1993,1995)$ som en resurs och på inläraren som aktiv meningsskapare varit vägledande.

\section{Resultat}

Litteracitetshändelser som kommer till uttryck i elevernas tal

De bilder eleverna hade med sig i sina mobiler och visade upp i intervjusituationen var främst bilder av olika slags skyltar såsom vägskyltar och skyltar exempelvis från affärer och varuhus. Dessutom förekom bilder från olika miljöer, som lekplats och bilparkering, samt bilder relaterade till deras sfi-studier. Ett exempel på det senare var ingången till den skola där de studerade och där många anslag med information fanns uppsatta, exempelvis om covid-19-pandemin och annat riktat till eleverna. En elev visade även upp en bild av den postlåda där han lämnade sina skrivuppgifter till den privata utbildningsanordnare där han studerade som komplement till sfi-undervisningen. Eleverna ombads berätta vad bilden visade och utifrån detta utvecklades intervjuerna till samtal om litteracitetshändelser relaterade till bilderna och annat i deras vardag.

Efter sammanställning av alla identifierade litteracitetshändelser sorterades dessa i tematiska områden. Det förekom inte skarpa gränser mellan olika teman, och en och samma händelse kunde ibland hänföras till flera teman. De innehållsteman som tydligast framträdde var händelser relaterade till (utan hänsyn tagen till grad av framträdande): inköp, myndighetskontakter och kallelser, social samvaro, kontakt med barnens förskola och skola, festarrangemang, religiösa sammanhang, informationshantering, nyheter och hantering av ekonomi.

Vid samtal om de skyltar från varuhus och affärer som visades på bild kom det fram att läsande av reklamerbjudanden av olika slag utgjorde litteracitetshändelser som de intervjuade fäste vikt vid. Samtliga berättade hur de mottog reklam såväl i pappersform via sin brevlåda som via sina mobiler, och att de var medlemmar i olika företag så att de fick reklam via mobiltelefonen vissa dagar i veckan. Företag som nämndes var främst klädkedjor och några större butikskedjor. Reklam från livsmedelskedjor 
fick de främst i pappersform. Att gå igenom reklamen var något som framträdde som litteracitetshändelser av betydelse på så sätt att flera sade sig veta vilka dagar olika företag skickade ut sin reklam och kunde visa upp reklam från olika företag de fått $i$ form av sms till sin mobil. Många beskrev hur de gick tillväga för att bedöma vilka varor som var prisvärda och berättade att efter att de hade bestämt sig gick de till den aktuella affären för att köpa dem. Hanifa beskrev hur hon hade valt att köpa en fläkt som erbjöds till ett rabatterat pris eftersom det just då var varmt (notera att de intervjuades tal framträder genom tolkning så att det är tolkens eller studiehandledarens tolkning som ges i excerptet). ${ }^{2}$

$\begin{array}{ll}\text { Hanifa: } & \text { Ja i förrgår jag har sett fläkt (jaha) i Jul i Jula } \\ \text { Intervjuare: } & \text { Ja Jula } \\ \text { Hanifa: } & \text { Jag gick det var varmt } \\ \text { Intervjuare: } & \text { Ja var det bordsfläkt eller var det takfläkt eller på bordet eller på golvet } \\ \text { Hanifa: } & \text { På golvet } \\ \text { Intervjuare: } & \text { På golvet golvfläkt ja det är inte vanligt att man har fläktar i Sverige } \\ & \text { men det blir varmare och varmare } \\ \text { Hanifa: } & \text { Det var måndag tisdag var } \\ \text { Intervjuare: } & \text { Kostade det mycket en sån fläkt } \\ \text { Hanifa: } & \text { Tvåhundra det var rabatt }\end{array}$

Någon nämnde även reklam i form av en utdelad reklamtidning och att den var för svår att läsa men att andra i familjen läste den.

Brev med information och kallelser från olika myndigheter var också något som alla mottog och läste. Alla sade sig kunna förstå något $\mathrm{i}$ dessa men ingen kunde förstå allt. Datum och plats samt avsändare var sådant som alla i stort sett kunde förstå. Dessa brev betraktades som viktiga och om någon behövde hjälp med att exempelvis svara eller ändra någon tid så hade denna möjlighet att skaffa sådan hjälp genom andra personer eller digitala verktyg. Vissa myndighetskontakter var kombinerade med social samvaro. Detta gällde exempelvis babycafé som några hade deltagit $i$ innan covid-19 hade stoppat den verksamheten. Dit brukade någon bjudas in för att ge information, såsom en läkare eller en representant från exempelvis Försäkringskassan eller Skattemyndigheten. Ofta delades då också broschyrer eller annan form av skriftlig information ut, men ingen sade sig läsa dessa. En kallelse kunde innebära ett behov av att ta buss för att ta sig till ett möte eller en tid på vårdcentralen och Hanifa beskrev hur hon hanterade det:

Hanifa: $\quad$ Föst jag tittar här (visar fram mobilen) om det finns tidtabell annars

Intervjuare: Och annars tittar du där det står X-stad (ja) ja men du förstår tidtabellen där också i mobilen

Hanifa: $\quad$ Det är svårt man läser men ibland det står skyltar vad heter tv som sitter

Intervjuare: Ja på väggen precis

Hanifa: $\quad$ Man har tid att (xx) hjärnan man kommer ihåg

${ }^{2}$ I transkripten står (...) för uteslutet tal och (xx) för ohörbart. 
Det var alltså den nedladdade tidtabellen i mobilen och tv-skärmen vid busshållplatsen i kombination med det egna minnet som var de verktyg hon använde. Hon säger att hon med hjälp av mobilen även kan hantera förändringar i tidtabeller.

Alla intervjuade, utom en, hade barn i förskola och/eller skola och information därifrån mottogs på tre olika sätt: som brev med posten, i form av ett papper som barnet tog med hem eller genom mobilen via den lärportal som denna kommun använde. Olika skolor och förskolor lämnade informationen på olika sätt och alla intervjuade sade sig läsa och kunna förstå, men oftast med hjälp av någon, exempelvis barnet ifråga självt eller någon annan i familjen. Den egna kontakten med förskola och skola, exempelvis för att ändra en tid, ansöka om ledighet eller meddela barnets frånvaro, skedde i vissa fall via telefonsamtal, i andra via sms eller skriftlig blankett som skickades med eleven. Flera uttryckte särskilt sitt beröm över en skola som själva skickade hem blanketter så att föräldrar kunde begära ledigt vid större högtider, såsom vid Idd el Fitr. Zeyneb säger:

Zeyneb: Dom är också duktiga och dom vet mera dom vet om det kommer Idd eller nån högtid dom brukar lämna själv skolan lämnar blankett till barnen (ok) ge det här till föräldrarna om ni behöver ta ledigt en dag två dar tre dar

Intervjuare: $\quad \mathrm{M}$ så det händer aldrig att du behöver fråga skol eller lämna nån lapp till skolan du behöver inte skriva nåt till skolan

Zeyneb: Mesta det som dom skickar

Yosuf berättade att vid viktiga tillfällen, som om något barn upplevde problem med andra kamrater i skolan, gick han själv dit och pratade med lärarna. Det hade enligt honom alltid löst problemet.

Flera av de intervjuade berättade att de, i samband med större fester såsom vid bröllop, skickade eller mottog inbjudningskort, men för övrigt uttrycker de att alla förberedelser, som planering, inköp och matlagning, skedde "i huvudet" och genom att man bjöd in några vänner för att hjälpa till. Shukri och Habibu berättar:

Shukri: $\quad$ Om det är till exempel bröllopsfest just då den personen som har bröllop eller festen är det väl som bjuder folket till festen och vi får inbjudningskort och liknande och det är så vi brukar gå till olika fester och det är hon eller han då som anordnar allting

Intervjuare: Har ni anordnat en sån fest har ni anordnat ett bröllop

Habibu: Ja

Intervjuare: Hu hur giorde du med mat var du ensam eller var ni flera som hjälptes åt?

Habibu: I så fall så är man fler personer

Intervjuare: $\quad \mathrm{M}$ och då tänker jag hur gör man när man handlar då så då kan man ju inte handla kanske ett kilo kött utan man måste ha många och olika sorter hur gör ni planerar ni tillsammans eller går man iväg och handlar bara eller skriver ni ner nån lista

Habibu: $\quad$ Em jo så här just den personen som kommer att ha festen eller den som bjuder sina vänner för att hjälpa en och på så sätt kan man planera hur man ska göra inköpen hur man ska laga mat och hur man ska göra och så vidare så det är hon eller han som bestämmer 
Intervjuare: Ok men det är inte att man skriver ner att du ska handla så mycket och och du ska laga det utan man bara pratar och kommer överens och så håller man det håller man hela planeringen i huvudet

Habibu: Det är personen som har bjudit eller som ska bjuda folk till festen som håller i planeringen som har planerat allting då topp till tå och hon behöver bara hjälp från oss det kanske kommer att finnas folk som ska vara hemma för att hjälpa till med matlagningen det är alltså hon kommer att ha med sig liksom följer henne för att göra inköpen

Några av eleverna berättade att de hade gått i koranskola, att de kunde läsa och skriva arabiska, och att de brukade läsa Koranen tillsammans med familjen, främst på kvällen strax innan bönen. De två kurdiska eleverna hade gått i arabiskspråkig skola och uppgav att de kunde läsa någon arabiska men inte kurdiska. Av de somaliska var det några som uppgav att de kunde läsa somaliska och några att de kunde läsa arabiska.

Förutom information som kom via posten var det också några som berättade att de brukade använda digitala verktyg för att söka information och för att översätta information som de fått i skriftlig form. De flesta hade olika slag av appar i sina mobiler som de använde för översättning såväl av enstaka skrivna eller talade ord som sådana där de kunde fotografera av en text och få den översatt. Flera elever berättade även om användning av Google för att söka information. Hasan, exempelvis, sade att han brukar söka på Google om han är oense med någon om något.

Hasan: Ja jag frågar Google ibland om nån inte är överens om nåt svar då frågar dom Google

Intervjuare: (skratt) brukar du ha rätt eller den andre ha rätt

Hasan: $\quad$ Ibland ja ibland nej det är ibland jag som vinner det är ibland den andra (...)

Hasan: (xx) Somalia var dog han till exempel vilket land till exempel han dog i Nigeria (m) jag och den där personen som var inte överens var dog Muhammed (xx)

Intervjuare: Och då hitt

Hasan: Det var jag som vann

Intervjuare: Och du hi ni hittade det

Hasan: Ja vi hittade det vi var inte överens

Han sade också att han ibland läser på en webbsajt från hemlandet. För övrigt var det inte många som nämnde informationssökande, men vissa berättade att de tittade på nyheter. Dimal och Salma nämnde Rapport men att det var lite för svårt att förstå och att de brukade behöva be någon förklara. Dagligen återkommande nyheter på olika språk som de hittade på YouTube eller Facebook, och både med tal och text, beskrev bland annat Dimal att hon använde. Hon berättade exempelvis hur hon läste texten på arabiska och lyssnade på svenska. Två av eleverna nämnde att de hade lånat en bok på biblioteket och läst men bara en av dem kom ihåg innehållet. Boken hade handlat om Sveriges historia och bilderna hade gett stöd för läsandet. Några nämnde att de brukade se engelskspråkiga filmer och då försökte läsa svenska undertexter, men att det var svårt att hinna med. De brukade då stoppa programmet då och då för att läsa men detta kunde irritera andra i familjen. 
Alla elever hade olika strategier för att hantera ekonomiska frågor, såsom att leta efter varor med lågt pris och att ta separat kvitto när man handlade åt någon bekant för att få tillbaka rätt summa. Hanifa beskrev hur hon tog ut sina pengar och gjorde en budget varje månad genom att sortera pengarna utifrån vad de skulle användas till.

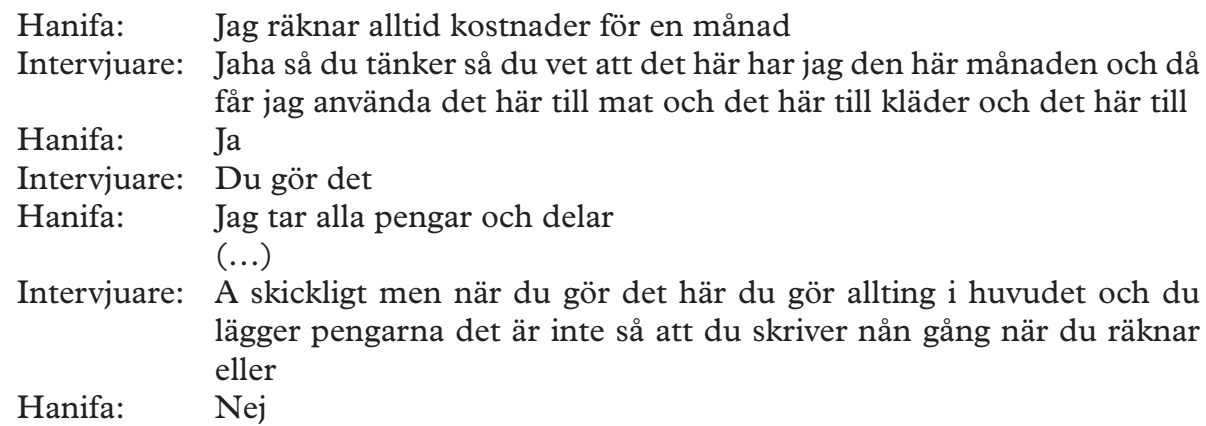

Alla elever beskrev hur de försökte jämföra priser på olika sätt innan de bestämde sig för vad de skulle köpa och Shukri sade att hon valde stora förpackningar eftersom de räcker längre.

Sammantaget framträder en variation av litteracitetshändelser i vardagslivet där särskilt samhällsdomänen framstår som en domän där skrift används. Läsande framträder starkare än skrivande, och variationen är stor vad gäller hur mycket de intervjuade kan läsa och förstå själva och vad de behöver hjälp med. Det skrivande som nämns kan förstås som relativt begränsat och består främst av att fylla i blanketter och skicka sms. Det senare förefaller dock vara mindre vanligt än att skicka en bild eller att ringa. Vad gäller kommunikation med anhöriga och vänner i hemlandet nämns bara samtal via telefon eller mobil och inte någon skriftlig form. Med tanke på den stora betydelse som skrift har i samhället blir det tydligt att färdigheter i hantering av skrift är betydelsefulla för deras deltagande i samhällslivet. Samtidigt kan avsaknad av förekomst av litteracitetshändelser kopplade till arbetslivet säga något om dessa elevers svaga ställning på arbetsmarknaden, och därmed avsaknad av en viktig domän för den enskildes ekonomiska villkor och sociala samvaro, en domän som samtidigt är starkt kopplad till status. Av de litteracitetshändelser från hemmet som eleverna beskrev var det flera där de sade sig behöva hjälp av andra, som vid läsande av kallelser och brev.

Elevernas upplevelse av huruvida deras färdigheter är tillräckliga för dessa händelser När det gäller hur den egna förmågan uppfattas kan man tänka sig att eleverna som vuxna kan uppleva motstånd mot att visa fram brister. Samtidigt befann sig alla, som sfielever i början av studieväg ett, $i$ en situation där de redan har kategoriserats som personer med låga litteracitetsfärdigheter. Några av eleverna befann sig också $\mathrm{i}$ en situation där de inom kort skulle skrivas ut från sfi på grund av bristande progression enligt skolans bedömning, vilket i princip innebar att deras möjligheter till studier 
skulle försvinna. Även om eleverna i intervjuerna aldrig blev direkt tillfrågade om huruvida de upplevde sig ha tillräckliga färdigheter vad gäller läsning och skrivning använde de själva ord som "svårt" när de talade om att läsa och att skriva och de beskrev många situationer där deras egna litteracitetsfärdigheter inte räckte till.Yosuf svarade på frågan om huruvida han kunde läsa och förstå de kallelser och den information av olika slag han fick på posten:

Yosuf: $\quad$ Måste jag göra det om man måste tänka om man har huvud så man måste tänka om det finns ett nåt nytt ord

(...)

Jag översätter ordet om jag inte förstår

Här ser vi hur han betonar förståelsen av specifika ord och att det var viktigt för honom att kunna hantera att han inte förstod allt. En annan situation i hemdomänen som behandlades $i$ intervjuerna var matlagning. Flera beskrev att de lagar mat utan skrivna recept och visade en stolthet över att klara sig utan skrift vid matlagningen. Hanifa sade:

Hanifa: Till exempel det var en kvinna som har frågat, svensk kvinna som har frågat kan du ge mig receptet på sambusa

Intervjuare: Ja ja

Hanifa: Jag sa jag har inget recept

Att slå upp betydelsen av enskilda ord i brev som kommer visar på ett behov av att förstå innehållet och att de egna språkfärdigheterna ibland inte räcker för detta. Att laga mat utan skrivna recept och uttrycka att man är nöjd med resultatet, däremot, visar inte på något upplevt behov av utökade färdigheter.

Läsande av reklam var en framträdande litteracitetshändelse och Hasan sade att reklam och annan post som kommer är till hans familj och inte till honom. Han utryckte inte att det skulle bero på att han ser sina egna färdigheter som bristfälliga utan att det beror på ett ointresse.

Intervjuare: Kommer det reklam brukar du titta på reklam

Yosuf: Jag är inte intresserad

Intervjuare: Du är inte intresserad av det

Yosuf: $\quad$ Nej

Intervjuare: Kommer det nåt annat med posten

Yosuf: $\quad$ Till familjen inte till mig

Även litteracitetshändelser i samband med att handla mat eller andra varor framstår som relativt betydelsefulla, även om Shukri sade att hon inte läste något inne i affären. Zeyneb berättade att det hade hänt att hon kommit hem med fel vara för att hon ibland inte hinner titta på förpackningen och det blir fel. Samtidigt behöver det inte säga något om förmågan att läsa eftersom det kan finnas många andra orsaker till att man ibland kommer hem med fel vara.

När Habibu visade en av sina bilder från lekparken fanns en hög, gul skylt med svart text med lekparkens namn mitt i bilden. På frågan om hon visste vad det står 
på den sade hon sig inte ha lagt märke till texten på den. Ett annat liknande exempel kan hämtas från hennes och Shamsus kommentar till bilden av skolingången där en mängd anslag sitter på dörr och vägg. När de blev tillfrågade om de brukar läsa dessa och annan information som finns uppsatt $i$ anslutning till ingången sade de att de kan läsa och förstå anslagen men inte gör det.

Vad som kan betraktas som tillräckliga färdigheter är inte något entydigt utan bland annat beroende av upplevda behov. Att i en lekpark inte läsa en skylt med dess namn kan uppfattas som att behovet av att läsa det inte var stort. Samtidigt innehöll de uppsatta lapparna vid skolans ingång väsentlig information till eleverna som de därmed riskerade att gå miste om. Man kan också tänka att det kan upplevas begränsande att inte hinna läsa undertexten på en film man ser och att som vuxen vara tvungen att be om hjälp för att förstå information från exempelvis förskola, skola och andra myndigheter. Detta uttrycktes inte direkt av eleverna och det kan också vara så att olika elever upplever detta som bristande färdigheter i olika utsträckning.

Att färdigheter i läsning och skrivning är betydelsefulla för arbetslivet blir indirekt synligt genom att ingen av de intervjuade hade en anställning, förutom Hasan med sporadiska timmar. Dimal sade att hon hade försökt få bageriarbete men blivit nekad på grund av att hon saknar sfi-betyg. Med tanke på att dessa elever har lång väg till ett sfi-betyg blir det tydligt att färdigheter i läsning och skrivning blir ett avgörande hinder. När det gäller hemmet blir däremot inte hinder orsakade av bristande läsoch skrivförmåga direkt synliga. De som sade sig inte hinna förstå nyhetsprogram som Rapport och inte kunna läsa det utdelade reklambladet angav att de fick hjälp av andra i hemmet, anhöriga som därför kan tänkas ha större färdigheter.

Liksom deltagarna i Prinsloo och Breier (1996) och Martin-Jones och Jones (2000) möter dessa deltagare situationer där deras egna litteracitetsfärdigheter i viss mån begränsar dem. Olika mönster framträder där eleven antingen 1) saknar färdigheter att klara av en aktivitet som involverar skrift som denna vill eller har behov av att utföra, 2) klarar av att genomföra något utan skrift och därmed inte ser ett behov av skriften, 3) tar hjälp av en annan person för att genomföra något när de egna skriftliga färdigheterna inte räcker till eller 4) inte upplever behov av att genomföra en aktivitet som involverar skrift eftersom närstående personer gör det åt eleven.

\section{Strategier för att hantera situationer där egna färdigheter inte räcker till}

Alla intervjuade elever berättade om olika slags strategier de använder för att hantera litteracitetshändelser där de egna färdigheterna inte är tillräckliga. Digitala verktyg är viktiga, och man använder sig av olika minnesstrategier, av ledtrådar i form av tidigare känd information och tar hjälp av mediatorer. Ofta används en kombination av olika strategier.

Strategier som innebär användning av digitala verktyg är betydelsefulla. Ett exempel på användning av mobil är att använda appar för översättning och även att be om hjälp via exempelvis sms eller att ringa. Hanifa sade att om hon inte förstår försöker hon översätta via Lexin på mobilen eller fråga om hjälp. Hon använder ofta mobilen 
för att be sina barn att hjälpa henne och de har lärt henne exempelvis vilket schampo hon ska välja. Om hon inte hittar den sorten eller om det är en ny förpackning skickar hon en bild till barnen så svarar de och meddelar om det är ett bra val eller inte.

Informanterna använder sig av tidigare kunskap på olika sätt. I samband med handling i affärer är en strategi som nämndes att hålla i minnet vad man ska handla. En annan strategi är att räkna ihop vad det kostar allt eftersom man handlar för att försäkra sig om att pengarna räcker. Zeyneb berättade även om en strategi att använda sig av känd information för att förstå sådant som är för svårt att läsa; att hitta bland olika slags kryddor i affären. Hon tittar på första bokstaven på förpackningen, och eftersom det, när det gäller just kryddor, finns flera som inleds med exempelvis $\mathrm{K}$, som kanel, kardemumma, kryddnejlikor etc., brukar hon också titta i burken för att se att det ser rätt ut.

Mediatorer av olika slag används på olika sätt. I affärer är en strategi att fråga personalen när man inte kan hitta det man söker. Zeyneb berättade om en gång när förpackningen hade ändrats så att hon inte kunde hitta den mjölk hon ville köpa. Då frågade hon en av de anställda som visade hur den förpackning hon sökte såg ut nu. Även när det gäller skriftliga meddelanden från skolan använder Zeyneb, liksom flera av de andra, ofta strategin att barnen får läsa och förklara. Flera av eleverna berättade om ett servicekontor dit man kan gå och få hjälp med papper och blanketter och där det också finns personer som talar somaliska och kurdiska, och de sade sig gå dit när de behöver.

Olika strategier som innebär tillrättaläggande eller anpassning av litteracitetshändelser används också. Exempelvis berättade Zeyneb att hon har sagt till i förskolan och skolan att när det gäller viktig information, såsom vilken dag och tid barnen ska börja i förskoleklass, vill hon hellre få den på papper än i mobilen för att hon då har större möjlighet att läsa och förstå.

Sammantaget har de intervjuade eleverna utvecklat olika strategier för att hantera litteracitetshändelser som kräver färdigheter de ännu inte har utvecklat. Viktiga mediatorer är familjemedlemmar, varav särskilt barnen nämns, och därutöver även grannar och andra bekanta samt myndighetspersoner. Digitala verktyg som översättningsappar är också viktiga, liksom möjligheten att skicka meddelanden och bilder via mobil. Samtidigt kunde vi observera under intervjuerna att de mobiler de använde hade rätt små skärmar och var av relativt enkla modeller, även om samtliga nio intervjuade hade smartphones. Appar de beskrev att de använde fanns inte alltid i mobilen just då och sådant de ville visa kunde de inte alltid hitta. Här är det möjligt att en svag ekonomisk situation försvårar strategier där mobiler används, inte minst vad gäller begränsning av surfmängd.

\section{Diskussion och slutsatser}

För att möjliggöra en undervisning som bygger på elevers behov i vardagslivet är begreppet litteracitetspraktiker i Streets definition (2003) värdefullt liksom funds of knowledge (González et al., 2005). Genom analys av elevernas tal om litteracitetshändelser de 
deltar i och strategier de använder när deras färdigheter inte räcker till framträder en bild av deras användning av skrift för meningsskapande, deras litteracitetspraktiker. Relationer mellan undervisningen och maktrelationer i lokala diskurser framträder bland annat i form av elevernas beroende av välvilliga mediatorer och av digitala resurser som är kopplade till ekonomiska möjligheter. Även om eleverna inte direkt uttrycker att de saknar färdigheter framgår det att de behöver och får hjälp. Huruvida de upplever att denna hjälp är tillräcklig eller om de upplever att de begränsas i detta framgår inte explicit.

Litteracitetspraktiker relaterade till arbetsliv är här relativt osynliga, vilket kan vara förväntat med tanke på elevernas svaga ställning på arbetsmarknaden. Att sfi-betyget, dvs. betyg från kurs $\mathrm{D}$, är av värde för anställning och att litteracitetsfärdigheter av mer avancerad art krävs för detta är också tidigare känt, liksom det värde arbete har för den enskildas ekonomiska trygghet och tillskrivna status. Detta väcker frågan om status och roller i hemmet. För att kunna hävda sin roll som vuxen kan det betraktas som viktigt att själv kunna ta del av sådan information som man behöver utan att vara beroende av andra. Som förälder är det exempelvis viktigt att kunna delta aktivt i litteracitetspraktiker där det krävs att man kan tillgodogöra sig och meddela information till sina barns förskola och skola utan att vara beroende av stöd från sina barn. Ett sådant beroende kan även innebära svårigheter att hävda sin roll som förälder.

Som vuxen är det också viktigt att ha möjlighet att själv kunna föra sin talan i myndighetsärenden man är berörd av, och då är litteracitetsfärdigheter betydelsefulla. Alltför låga färdigheter innebär att man riskerar att bli begränsad i sitt samhälleliga deltagande och få svårt att utöva sina medborgerliga rättigheter. I Sverige värderas individens självständighet högt medan de slag av nätverkande, ömsesidighet och att man hjälper varandra som vi ser exempel på här värderas lägre än på många andra håll (se exempelvis González et al., 2005, s. 18; Papen, 2005; Prinsloo \& Breier, 1996; Wedin, 2007). Ett exempel på just hur självständighet kontra ömsesidighet kan värderas olika är den sydafrikanska kvinna som Kell (1996) studerade och som var en betydelsefull person i sitt bostadsområde där hon medierade i litteracitetspraktiker i relation till samhällslivet, men som i de kvällskurser där hon deltog betraktades som analfabet (se även Wedin, 2007). En risk finns således att brister i läs- och skrivfärdigheter medför beroende av andra och begränsning vad gäller möjligheter att hävda sin rätt både i hemmet och i samhället. Det stora värde som finns $i$ att ha människor i familjen och i andra sammanhang som kan hjälpa en behöver ställas mot den beroendesituation det kan innebära för den enskilda. Elevernas utveckling av förmågor i läsning och skrivning kan medföra förskjutning i maktrelationer, och litteracitetsutvecklingen är därför nära kopplad till frågor om individens rättigheter $i$ relation till sociala frågor av betydelse för familjeliv, samverkan och nätverkande.

De litteracitetspraktiker som framträder aktualiserar olika funds of knowledge (González et al., 2005) i form av en variation av färdigheter och kreativitet vad gäller 
att skapa och använda strategier som utgör en utvecklingspotential för undervisningen, inte minst vad gäller hantering av ekonomiska frågor. Engagemanget bland de intervjuade var stort $\mathrm{i}$ frågor som rörde ekonomi, liksom kreativiteten vad gäller att skapa strategier för att lösa frågor relaterade till skriftspråksanvändning, såsom vid inköp till hushållet. Där beskrev de intervjuade utvecklade strategier både för ekonomisk planering och kritiskt förhållningssätt som konsument. Engagemang och investering är viktigt vid all språkutveckling (Cummins, 2017; Norton, 2001, 2013) och inte minst vad gäller skriftspråksutveckling (Norlund Shaswar \& Wedin, 2019). Denna studie visar att frågor av relevans för eleverna själva väcker sådant engagemang och att de är villiga att investera mycket tid och kraft i detta.

Studien visar också att genom ett synliggörande av elevers funds of knowledge (González et al., 2005), i detta fall genom av litteracitetspraktiker i vardagslivet, framträder många olika aspekter på elevers litteracitetsfärdigheter och strategier för språkanvändning. Om sfi-lärare samtalar med elever om deras läsande och skrivande i vardagslivet kan de få syn på delar av elevernas litteracitetsfärdigheter som de inte tidigare varit medvetna om, vilket kan innebära att de finner nya vägar att utforma en undervisning som berör och engagerar eleverna.

Vidare kan arbete med frågor av kritisk art vara särskilt värdefullt för litteracitetsundervisningen, både för att utveckla kompetenser vad gäller kritisk litteracitet och för att engagera och därmed stimulera till ökat läsande och skrivande. Det kan exempelvis handla om att $\mathrm{i}$ undervisningen kritiskt granska reklamerbjudanden såsom bildbudskap och jämförelser av priser, eller att kritiskt granska nyhetsrapportering, exempelvis genom jämförelse av rapportering på olika språk och i olika länder. Det kan också handla om att $\mathrm{i}$ undervisningen behandla frågor om roller och status i vardagslivet. Därtill ser vi även att ett arbete med elevers inlärarstrategier har stor potential att utveckla sfi-undervisning på studieväg ett. Genom att lärare får kännedom om strategier som eleverna använder i vardagslivet kan undervisningen utvecklas på sätt som gynnar elevernas andraspråksutveckling.

\section{Tackord}

Vi vill uttrycka vårt varma tack till de elever som generöst delat med sig av sina tankar och erfarenheter och samtidigt Skolforskningsinstitutet som möjliggiort denna studie.

\section{Forfatterbiografi}

Åsa Wedin är fil dr i tvåspråkighetsforskning och professor i pedagogiskt arbete vid Högskolan Dalarna. Hon arbetar med lärarutbildning och forskning med inriktning mot flerspråkighet och litteracitet med särskilt intresse för yngre barn och vuxna. Hon arbetar för närvarande med ett projekt om sfi och ett om nyanlända elever på gymnasiet, och har publicerat flera böcker inom dessa områden. 
Annika Norlund Shaswar är fil dr i språkvetenskap och lektor i språkdidaktik med inriktnign mot svenska som andraspråk vid Umeå universitet. Hon är verskam inom lärarutbildningen och har publicerat forskning och litteratur för verksamma lärare om litteracitet och flerspråkighet, främst med inriktning mot lågutbildade vuxna.

\section{Referenser}

Ahlgren, K. (2014). Narrativa identiteter och levande metaforer $i$ ett andraspråksperspektiv [Doktorsavhandling]. Stockholms universitet.

Barton, D. (2001). Literacy in everyday contexts. I L. Verhoeven \& C. Snow (Red.), Literacy and motivation: Reading engagement in individuals and groups (s. 23-38). Lawrence Erlbaum associates.

Barton, D. \& Hamilton, M. (1998). Local literacies: Reading and writing in one community. Routledge.

Barton, D. \& Hamilton, M. (2000). Literacy practices. I D. Barton, M. Hamilton \& R. Ivanič (Red.), Situated literacies: Reading and writing in context (s. 7-15). Routledge.

Barton, D., Ivanič, R., Appleby, Y., Hodge, R. \& Tusting, K. (2007). Literacy, lives and learning. Routledge.

Baynham, M. \& Prinsloo, M. (2009). Introduction: The future of Literacy Studies. I M. Baynham \& M. Prinsloo (Red.), The future of literacy studies (s. 1-20). Palgrave Macmillan.

Bialystok, E. (2001). Bilingualism in development: Language, literacy, and cognition. Cambridge University Press.

Canagarajah, A. S. (2006). Ethnographic methods in language policy. I T. Ricento (Red.), An introduction to language policy: Theory and method (s. 153-169). Blackwell.

Carlson, M. (2002). Svenska för invandrare - brygga eller gräns? Syn på kunskap och lärande inom sfi-undervisningen [Doktorsavhandling, Göteborgs universitet]. GUPEA. http://hdl.handle.net/2077/15725

Choi, J. \& Ziegler, G. (2015). Literacy education for low-educated second language learning adults in multilingual contexts: The case of Luxembourg. Multilingual Education, 5(4), 1-21. https://doi.org/10.1186/s13616015-0024-7

Colliander, H. (2018). The experienced newcomer: The (trans)forming of professional teacher identity in a new landscape of practices. Teaching and Teacher Education, 69, 168-176. https://doi.org/10.1016/j.tate. 2017.10.012

Cooke, M. (2006). "When I wake up I dream of electricity": The lives, aspirations and 'needs' of Adult ESOL learners. Linguistics and Education, 17(1), 56-73.

Copland, F. \& Creese, A. (2015). Linguistic ethnography: Collecting, analysing and presenting data. Sage.

Cummins, J. (2017). Flerspråkiga elever: Effektiv undervisning i en utmanande tid. Natur \& Kultur.

Dantas, M. L. \& Manyak, P. C. (Red.). (2010). Home-school connections in a multicultural society: Learning from and with culturally and linguistically diverse families. Routledge.

Franker, Q. (2011).Litteracitetoch visuella texter:Studierom lärare och kortutbildade deltagare isf $[$ [Doktorsavhandling, Stockhoms universitet]. DiVA. http://www.diva-portal.org/smash/get/diva2:386054/FULLTEXT01.pdf

Freire, P. (1970). Pedagogy of the opressed. Continuum.

González, N., Moll, L. S. \& Amanti, C. (Red.). (2005). Funds of knowledge. Theorizing practices in households, communities and class-rooms. Lawrence Erlbaum associates.

Griffiths, C. (2013). The strategy factor in successful language learning. Multilingual Matters.

Haglund, B. (2003). Stimulated recall: Några anteckningar om en metod att generera data. Pedagogisk Forskning $i$ Sverige, 8(3), 145-157.

Hamilton, M. (2000). Expanding the New Literacy Studies: Using photographs to explore literacy as a social practice. I D. Barton, M. Hamilton \& R. Ivanič (Red.), Situated literacies: Reading and writing in context (s. 16-34). Routledge.

Heath, S. B. (1982). Protean shapes in literacy events: Ever-shifting oral and literate traditions. I D. Tannen (Red.), Spoken and written language: Exploring orality and literacy (s. 91-118). ABLEX Publishing Corporation.

Hornberger, N. \& Johnson, D. C. (2017). Slicing the onion ethnographically: Layers and spaces in multilingual language education policy and practice. TESOL Quarterly, 41(3), 509-532.

Kell, C. (1996). Literacy practices in an informal settlement in the Cape Peninsula. In M. Prinsloo \& M. Breier (Red.), The social uses of literacy (s. 235-256). Sached Books.

Kerfoot, C. (2009). Changing conceptions of literacies, language and development: Implications for the provision of adult basic education in South Africa. [Doktorsavhandling, Stockholms universitet]. DiVA. http://www.diva-portal. org/smash/get/diva2:212620/FULLTEXT01.pdf 


\section{Litteracitetspraktiker $i$ vardags- och samhällsliv}

Lam, W. S. E., Warriner, D. S., Poveda, D. \& González, N. (2012). Transnationalism and literacy: Investigating the mobility of people, languages, texts, and practices in contexts of migration. Reading Research Quarterly, 47(2), 191-215.

Li, G. (Red.). (2009). Multicultural families, home literacies, and main-streams Schooling. Information Age Publishing.

Lindberg, I. \& Sandwall, K. (2017). Conflicting agendas in Swedish adult second language education. I C. Kerfoot \& K. Hyltenstam (Red.), Entangled discourses: South-North orders of visibility (s. 119-13). Routledge.

Lundgren, B. (2005). Skolan i livet - livet i skolan: Några illitterata invandrarkvinnor lär sig tala, läsa och skriva på svenska som andraspråk [Doktorsavhandling, Umeå universitet]. DiVA. https://www.diva-portal.org/smash/ get/diva2:143664/FULLTEXT01.pdf

Lundgren, B., Rosén, J. \& Jahnke, A. (2017). 15 års forskning om sfi-en överblick: Förstudie inför ett Ifous FOUprogram. Ifous - Academedia.

Malessa, E. (2018). Learning to read for the first time as adult immigrants in Finland: Reviewing pertinent research of low-literate or non-literate learners' literacy acquisition and computer-assisted literacy training. Apples: Fournal of Applied Language Studies, 12(1), 25-54. https://doi.org/10.17011/apples/urn. 201804051932

Martin-Jones, M. (2007). Bilingualism, education and the regulation of access to language resources. I M. Heller (Red.), Bilingualism: A social approach. (s. 161-182). Palgrave.

Martin-Jones, M. \& Jones, K. (Red.), (2000). Multilingual literacies. John Benjamin Publishing Company.

Menard-Warwick, J. (2009). Gendered identities and immigrant language learning. Multilingual Matters.

Monsen, M. (2021). Om å investere i R-U-M-P-E: En etnografisk studie av lese- og skriveopplæringen for voksne nyankomne. I M. Monsen \& V. Pájaro (Red.), Andrespråkslcering hos voksne:Vitenskapelige innsikter og didaktiske refleksjoner (s. 130-145). Cappelen Damm Akademisk.

Monsen, M. \& Pájaro, V. (Red.). (2021). Andrespråkslcering hos voksne: Vitenskapelige innsikter og didaktiske refleksjoner. Cappelen Damm Akademisk.

Noguerón-Liu, S. (2013). Access to technology in transnational social fields: Simultaneity and digital literacy socialization of adult immigrants. International Multilingual Research fournal, (7), 33-48. https://doi.org/10.1080/19313152.2013.746801

Norlund Shaswar, A. (2014). Skriftbruk $i$ vardagsliv och $i$ sfi-utbildning. En studie av fem kurdiska sfi-studerandes skriftbrukshistoria och skriftpraktiker. [Doktorsavhandling, Umeå universitet]. DiVA. http://umu.diva-portal. org/smash/get/diva2:761398/FULLTEXT01.pdf

Norlund Shaswar, A. (2021). 'I should really interpret word by word for you': Researcher, interpreter and interviewee negotiating roles, responsibilities and meanings in two multilingual literacy research interviews. I E. O. Breuer, E. Lindgren, A. Stavans \& E. Van Steendam (Red.), Multilingual Literacy (s. 63-93). Multilingual Matters.

Norlund Shaswar, A. \& Wedin, Å. (2019). Language learning strategies and teaching practices in adult L 2 education: The case of Swedish for Immigrants. Apples - Fournal of Applied Language Studies, 13(3), $17-34$.

Norton, B. (2013). Identity and language learning: Extending the conversation. Multilingual Matters.

Norton, B. (2015). Identity, investment, and faces of English internationally. Chinese fournal of Applied Linguistics, 38(4), 375-391.

Oxford, R., Rubin, J., Chamot, A. U., Schramm, K., Lavine, R., Gunning, P. \& Nel, C. (2014). The learning strategy prism: Perspectives of learning strategy experts. System, 43, 30-49.

Papen, U. (2005). Literacy and development: What works for whom? Or, how relevant is the social practices view of literacy for literacy education in developing countries? International fournal of Educational Development, 25(1), 5-17. https://doi.org/10.1016/j.ijedudev.2004.05.001

Pennycook, A. (2003). Critical applied linguistics: A critical introduction. Lawrence Erlbaum.

Pink, S. (2014). Digital-visual-sensory design anthropology; Ethnography, imagination and intervention. Arts \& Humanities in Higher Education, 13(4), 412-427.

Prinsloo, M. \& Breier, M. (Red.). (1996). The social uses of literacy. Sached Books.

Prosser, J. \& Loxley, A. (2008). Introducing visual methods. NCRM Methodological Review.

Purcell-Gates, V. (Red.). (2007). Cultural practices of literacy: Case studies of language, literacy, social practice, and power. Routledge.

Rosén, J. (2013). Svenska för invandrarskap? Språk, kategorisering och identitet inom utbildningsformen Svenska för invandrare. [Doktorsavhandling, Örebro universitet]. DiVA. http://urn.kb.se/resolve?urn=urn:nbn:se:du-13347 
Rydell, M. (2018). Constructions of language competence: Sociolinguistic perspectives on assessing second language interactions in basic adult education. [Doktorsavhandling, Stockholms universitet]. DiVA. http://urn.kb.se/ resolve?urn=urn:nbn:se:su:diva-158402

Scribner, S. \& Cole, M. (1981). The psychology of literacy. Harvard University Press.

Skilton-Sylvester, E. (2002). Should I stay or should I go?: Investigating Cambodian women's participation and investment in adult ESL programs. Adult Education Quarterly, 53(1), 9-26.

Skolinspektionen. (2018). Undervisning $i$ svenska för invandrare. Kvalitetsgranskning 2018. Diarienummer 4002016:6995. https:/www.riksdagen.se/sv/dokument-lagar/dokument/svensk-forfattningssamling/skollag2010800_sfs-2010-800 S

Skollag (2010:800 t.o.m. SFS 2021:452). Utbildningsdepartementet.

Skolverket. (2017). SKOLFS 2017:91, Kursplan för kommunal vuxenutbildning $i$ svenska för invandrare. https:// www.skolverket.se/undervisning/vuxenutbildningen/komvux-svenska-for-invandrare-sfi/laroplan-for-vuxoch-kursplan-for-svenska-for-invandrare-sfi/kursplan-for-svenska-for-invandrare-sfi

SOU 2013:76. (2013). Svenska för invandrare:Valfrihet, flexibilitet och individanpassning. Statens offentliga utredningar från Utbildningsdepartementet. https://www.regeringen.se/rattsliga-dokument/statens-offentliga-utredningar/2013/10/sou-201376/

SOU 2020:66. (2020). Samverkande krafter: För stärkt kvalitet och likvärdighet inom komvux för elever med svenska som andraspråk. Statens offentliga utredningar från Utbildningsdepartementet. https:/www.regeringen.se/ rattsliga-dokument/statens-offentliga-utredningar/2020/12/sou-202066/

Street, B. V. (1984). Literacy in theory and practice. Cambridge University Press.

Street, B. V. (1993). Cross-cultural approaches to literacy. Cambridge University Press.

Street, B. V. (1995). Social literacies critical approaches to literacy in development, ethnography and education. Longman Publishing.

Street, B. V. (2003). What's "new" in New Literacy Studies? Critical approaches to literacy in theory and practice. Current Issues in Comparative Education, 5(2), 77-91.

Street, B.V. (2009). “The future of 'social literacies"”. I M. Baynham \& M. Prinsloo (Red.), The future of literacy studies (s. 21-37). Palgrave Macmillan.

Street, B. V. (2011). Literacy inequalities in theory and practice: The power to name and define. International Fournal of Educational Development, 31(6), 580-586.

Warriner, D. S. (2010). Competent performances of situated identities: adult learners of English accessing engaged participation. Teaching and Teacher Education, 26(1), s. 22-30.

Wedin, A. (2007). Literacy and power: The cases of Tanzania and Rwanda. International fournal for Educational Development. http://doi.org/10.1016/j.ijedudev.2007.09.006

Wedin, Å., Rosén, J. \& Hennius, S. (2018). Transspråkande multimodalitet i grundläggande skriftspråksundervisning inom sfi. Pedagogisk forskning i Sverige, 23(1-2), 15-38.

Vollmer, S. (2019). Digital citizenship for newly arrived Syrian refugees through mobile technologies. I M. Cooke \& R. Peutrell (Red.), Brokering Britain: Educating citizens (s. 157-172). Multilingual Matters.

Zeichner, K. (2001). Educational action research. I P. Reason \& H. Bradbury (Red.), Handbook of action research: Participative inquiry and practice (s. 273-283). Sage. 